\title{
Front Matter: Volume 8987
}

, "Front Matter: Volume 8987," Proc. SPIE 8987, Oxide-based Materials and Devices V, 898701 (4 April 2014); doi: 10.1117/12.2063892

SPIE. Event: SPIE OPTO, 2014, San Francisco, California, United States 


\section{PROCEEDINGS OF SPIE}

\section{Oxide-based Materials and Devices $V$}

Ferechteh H. Teherani

David C. Look

David J. Rogers

Editors

2-5 February 2014

San Francisco, California, United States

Sponsored and Published by

SPIE 
The papers included in this volume were part of the technical conference cited on the cover and title page. Papers were selected and subject to review by the editors and conference program committee. Some conference presentations may not be available for publication. The papers published in these proceedings reflect the work and thoughts of the authors and are published herein as submitted. The publisher is not responsible for the validity of the information or for any outcomes resulting from reliance thereon.

Please use the following format to cite material from this book:

Author(s), "Title of Paper," in Oxide-based Materials and Devices V, edited by Ferechteh H. Teherani, David C. Look, David J. Rogers, Proceedings of SPIE Vol.8987 (SPIE, Bellingham, WA, 2014) Article CID Number.

ISSN: 0277-786X

ISBN: 9780819499004

Published by

SPIE

P.O. Box 10, Bellingham, Washington 98227-0010 USA

Telephone +1 3606763290 (Pacific Time) · Fax +1 3606471445

SPIE.org

Copyright (C) 2014, Society of Photo-Optical Instrumentation Engineers.

Copying of material in this book for internal or personal use, or for the internal or personal use of specific clients, beyond the fair use provisions granted by the U.S. Copyright Law is authorized by SPIE subject to payment of copying fees. The Transactional Reporting Service base fee for this volume is $\$ 18.00$ per article (or portion thereof), which should be paid directly to the Copyright Clearance Center (CCC), 222 Rosewood Drive, Danvers, MA 01923. Payment may also be made electronically through CCC Online at copyright.com. Other copying for republication, resale, advertising or promotion, or any form of systematic or multiple reproduction of any material in this book is prohibited except with permission in writing from the publisher. The CCC fee code is 0277-786X/14/\$18.00.

Printed in the United States of America.

Publication of record for individual papers is online in the SPIE Digital Library.

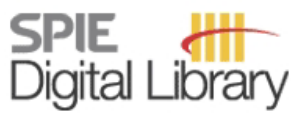

SPIEDigitalLibrary.org

Paper Numbering: Proceedings of SPIE follow an e-First publication model, with papers published first online and then in print and on CD-ROM. Papers are published as they are submitted and meet publication criteria. A unique, consistent, permanent citation identifier (CID) number is assigned to each article at the time of the first publication. Utilization of CIDs allows articles to be fully citable as soon as they are published online, and connects the same identifier to all online, print, and electronic versions of the publication. SPIE uses a six-digit CID article numbering system in which:

- The first four digits correspond to the SPIE volume number.

- The last two digits indicate publication order within the volume using a Base 36 numbering

system employing both numerals and letters. These two-number sets start with 00, 01, 02, 03, 04, $05,06,07,08,09,0 A, 0 B \ldots$. 0Z, followed by 10-1Z, 20-2Z, etc.

The CID Number appears on each page of the manuscript. The complete citation is used on the first page, and an abbreviated version on subsequent pages. Numbers in the index correspond to the last two digits of the six-digit CID Number. 


\title{
Contents
}

\author{
xi Conference Committee \\ $\mathrm{xV}$ Introduction
}

\section{SESSION 1 TRANSPARENT CONDUCTING OXIDES}

898702 Electrical properties of ultrathin Ga-doped ZnO films on Si and ZnO [8987-1]

D. C. Look, Wright State Univ. (United States), Wyle Labs., Inc. (United States), and Air Force Research Lab. (United States); B. Wang, Wright State Univ. (United States):

K. D. Leedy, D. B. Thomson, Air Force Research Lab. (United States)

$898703 \mathrm{TiO}_{2}$ anode materials for lithium-ion batteries with different morphology and additives [8987-68]

X. Liu, Y. H. Ng, Y. H. Leung, F. Liu, A. B. Djurišic, M. H. Xie, W. K. Chan, The Univ. of Hong Kong (Hong Kong, China)

898704 Mid-infrared extraordinary transmission through Ga-doped ZnO films with 2D hole arrays (Invited Paper) [8987-4]

J. W. Cleary, Air Force Research Lab. (United States); N. N. Nader Esfahani, S. Vangala, Air Force Research Lab. (United States), Solid State Scientific Corp. (United States), and Univ.

of Central Florida (United States); J. Guo, The Univ. of Alabama in Huntsville (United States); J. R. Hendrickson, K. D. Leedy, Air Force Research Lab. (United States); D. C. Look, Air Force Research Lab. (United States), Wyle Labs., Inc. (United States), and Wright State Univ. (United States)

898706 Numerical and experimental study of SnOx | Ag | SnOx multilayer as indium-free transparent electrode for organic solar cells [8987-76]

A. Bou, Institut Matériaux Microélectronique Nanosciences de Provence, CNRS, AixMarseille Univ. (France) and Crosslux (France); P. Torchio, D. Barakel, F. Thierry, Institut Matériaux Microélectronique Nanosciences de Provence, CNRS, Aix-Marseille Univ. (France); P.-Y. Thoulon, M. Ricci, Crosslux (France)

\section{SESSION 2 PHOTON-INDUCED PHENOMENA}

8987 OA Nanoscale optical and electrical characterizations of ZnO nanostructures by near-field microscopy (Invited Paper) [8987-9]

B. Bercu, L. Giraudet, M. Molinari, Univ. de Reims Champagne-Ardenne (France)

8987 OB Emission characteristics of electrically-and optically-pumped single ZnO micro-spherical crystal (Invited Paper) [8987-10]

D. Nakamura, T. Shimogaki, N. Tetsuyama, K. Fusazaki, Y. Mizokami, M. Higashihata,

H. Ikenoue, T. Okada, Kyushu Univ. (Japan) 
8987 OD Carrier dynamics in dilute II-VI oxide highly mismatched alloys (Invited Paper) [8987-12] Y.-C. Lin, W.-C. Chou, National Chiao Tung Univ. (Taiwan); J.-I. Chyi, National Central Univ. (Taiwan); T. Tanaka, Saga Univ. (Japan)

8987 OE Optical characterization of laterally and vertically structured oxides and semiconductors (Invited Paper) [8987-13]

P. Petrik, Technische Univ. Delft (Netherlands), Research Institute for Technical Physics and Materials Science (Hungary), and Univ. Pannonia (Hungary); N. Kumar, Technische Univ.

Delft (Netherlands); E. Agocs, Research Institute for Technical Physics and Materials

Science (Hungary); B. Fodor, Research Institute for Technical Physics and Materials Science (Hungary) and Univ. of Pécs (Hungary); S. F. Pereira, Technische Univ. Delft (Netherlands);

T. Lohner, Research Institute for Technical Physics and Materials Science (Hungary); M. Fried, Research Institute for Technical Physics and Materials Science (Hungary) and Univ. Pannonia (Hungary); H. P. Urbach, Technische Univ. Delft (Netherlands)

8987 OF Optical properties of ZnO thin films dispersed with noble metal nanoparticles synthesized by sol-gel method [8987-72]

M. Wakaki, T. Noguchi, E. Yokoyama, Tokai Univ. (Japan)

8987 OG Control of optical and electrical properties of $\mathrm{ZnO}$ nanocrystals by nanosecond-laser annealing [8987-78]

T. Shimogaki, T. Ofuji, N. Tetsuyama, H. Kawahara, M. Higashihata, H. Ikenove,

D. Nakamura, T. Okada, Kyushu Univ. (Japan)

$8987 \mathrm{OH}$ Electroluminescence from ZnO nanowire-based heterojunction LED [8987-79]

D. Nakamura, N. Tetsuyama, T. Shimogaki, M. Higashihata, H. Ikenove, T. Okada, Kyushu Univ. (Japan)

8987 Ol Effect of lithium-ion implantation of varying fluence on the optical properties of ZnMgO [8987-84]

S. Saha, S. Nagar, Indian Institute of Technology Bombay (India); S. K. Gupta, Bhabha Atomic Research Ctr. (India); S. Chakrabarti, Indian Institute of Technology Bombay (India)

8987 0J Optical properties and storage capabilities in $\mathrm{AB}_{2} \mathrm{O}_{4}: \mathrm{Cr}^{3+}(\mathrm{A}=\mathrm{Zn}, \mathbf{M g}, \mathrm{B}=\mathrm{Ga}, \mathrm{Al}$ ) [8987-93] S. K. Sharma, A. Bessiere, D. Gourier, G. Sraiki, B. Viana, IRCP, CNRS, Ecole Nationale Supérieure de Chimie de Paris (France); P. J. Dereń, D. Rudnicka, A. Watras, Institute of Low Temperature and Structure Research (Poland); N. Basavaraju, K. R. Priolkar, Goa Univ. (India); T. Maldiney, D. Scherman, C. Richard, Unité de Technologies Chimiques et Biologiques pour la Santé, CNRS, Univ. Paris Descartes (France)

\section{SESSION 3 DOPING AND BAND STRUCTURE STUDIES OF OXIDES}

8987 OK Polymorphism, band-structure, band-lineup, and alloy energetics of the group II oxides and sulfides MgO, ZnO, CdO, MgS, ZnS, CdS (Invited Paper) [8987-14]

S. Lany, National Renewable Energy Lab. (United States)

$8987 \mathrm{OL}$ Development of blue excitable persistent phosphor of $\mathrm{Ce}^{3+}$-doped garnet ceramics by bandgap engineering and metal sensitization (Invited Paper) [8987-15]

J. Ueda, K. Kuroishi, S. Tanabe, Kyoto Univ. (Japan) 
$8987 \mathrm{OM}$ Doping of $\mathrm{Ga}_{2} \mathrm{O}_{3}$ bulk crystals and NWs by ion implantation [8987-16]

K. Lorenz, M. Peres, M. Felizardo, J. G. Correia, L. C. Alves, E. Alves, Instituto Superior Técnico (Portugal); I. López, E. Nogales, B. Méndez, J. Piqueras, Univ. Complutense de Madrid (Spain); M. B. Barbosa, J. P. Araújo, Univ. do Porto (Portugal); J. N. Gonçalves, J. Rodrigues, L. Rino, T. Monteiro, Univ. de Aveiro (Portugal); E. G. Villora, K. Shimamura, National Institute for Materials Science (Japan)

SESSION 4 DOPING AND BAND STRUCTURE STUDIES OF ZNO

8987 OS Theoretical investigations of the electronic properties of functionalized zinc-oxide nanowires [8987-20]

M. Lorke, A. Domínguez, A. L. da Rosa, T. Fravenheim, Univ. Bremen (Germany)

\section{SESSION 5 HIGHLY-CORRELATED OXIDES I}

8987 OU Atomic collision effects during PLD processes: nonstoichiometry control in transparent superconductors (Invited Paper) [8987-21]

T. Hitosugi, D. Packwood, S. Shiraki, Tohoku Univ. (Japan)

8987 OV Augmented methods for growth and development of novel multi-cation oxides (Invited Paper) [8987-22]

H. Yamamoto, Y. Krockenberger, M. Naito, NTT Basic Research Labs. (Japan)

8987 OW Synthesis of epitaxial rutile-type $\mathrm{VO}_{2}$ and $\mathrm{VO}_{2}(\mathrm{~B})$ polymorph films (Invited Paper) [8987-23] F. J. Wong, S. Ramanathan, Harvard Univ. (United States)

\section{SESSION 6 HIGHLY-CORRELATED OXIDES II}

898710 Photocarrier recombination and localization dynamics of $\mathrm{LaAlO}_{3} / \mathrm{SrTiO}_{3}$ heterostructures [8987-27]

Y. Yamada, Kyoto Univ. (Japan); H. K. Sato, SLAC National Accelerator Lab. (United States) and The Univ. of Tokyo (Japan); Y. Hikita, SLAC National Accelerator Lab. (United States); H. Y. Hwang, SLAC National Accelerator Lab. (United States) and Stanford Univ. (United States); Y. Kanemitsu, Kyoto Univ. (Japan)

898711 Analysis of low temperature magnetoresistance of $\mathrm{LaAlO}_{3} / \mathrm{SrTiO}_{3}$ interfaces (Invited Paper) [8987-28]

S. Gariglio, A. Fête, D. Stornaiuolo, D. Li, Univ. de Genève (Switzerland); M. Gabay, Univ. Paris-Sud 11 (France); J.-M. Triscone, Univ. de Genève (Switzerland)

898712 Growth of crystalline $\mathrm{LaAlO}_{3}$ by atomic layer deposition (Invited Paper) [8987-29] T. Q. Ngo, M. D. McDaniel, A. Posadas, A. A. Demkov, J. G. Ekerdt, The Univ. of Texas at Austin (United States)

898713 Photon-induced thermoelectric voltages in complex oxide superlattices (Invited Paper) [8987-30]

H.-U. Habermeier, S. Heinze, Max-Planck-Institut für Festkörperforschung (Germany) 
898715 Raman study of magnetic phase transitions of hexagonal manganites [8987-95] J.-Y. Nam, N. T. M. Hien, N. T. Huyen, K. Han, Ewha Womans Univ. (Korea, Republic of); X.-B. Chen, Konkuk Univ. (Korea, Republic of); S. W. Cheong, Rutgers, The State Univ. of New Jersey (United States); D. Lee, T. W. Noh, Seoul National Univ. (Korea, Republic of); N. H. Sung, B. K. Cho, Gwangju Institute of Science and Technology (Korea, Republic of); I.-S. Yang, Ewha Womans Univ. (Korea, Republic of)

898716 Crystal, magnetic and dielectric studies of the 2D antiferromagnet: $\beta-\mathrm{NaMnO}_{2}$ [8987-71] I. Bakaimi, Foundation for Research and Technology-Hellas (Greece) and Univ. of Crete (Greece); A. Abakumov, Univ. Antwerpen (Belgium); M. A. Green, National Institute of Standards and Technology (United States) and Univ. of Kent (United Kingdom); A. Lappas, Foundation for Research and Technology-Hellas (Greece)

898717 Lattice location of $\mathrm{Hf}$ and its interaction with other impurities in $\mathrm{LiNbO}_{3}$ : an integrated review [8987-73]

J. G. Marques, K. Lorenz, Instituto Superior Técnico (Portugal)

\section{SESSION 7 THIN FILMS AND BULK PROCESSING}

898718 Is ZnO as a universal semiconductor material an oxymoron? (Invited Paper) [8987-58] B. Hussain, B. Kucukgok, M. Y. A. Raja, The Univ. of North Carolina at Charlotte (United States); B. Klein, Georgia Institute of Technology (United States); N. Lu, I. T. Ferguson, The Univ. of North Carolina at Charlotte (United States)

898719 Novel method for reclaim/reuse of bulk GaN substrates using sacrificial ZnO release layers (Invited Paper) [8987-33]

A. Rajan, Heriot-Watt Univ. (United Kingdom); S. Sundaram, Y. El Gmili, P. L. Voss, K. Pantzas, T. Moudakir, A. Ougazzaden, Georgia Tech-Lorraine, CNRS (France); D. J. Rogers,

F. Hosseini Teherani, V. E. Sandana, P. Bove, Nanovation (France); K. Prior, Heriot-Watt Univ. (United Kingdom); R. McClintock, M. Razeghi, Northwestern Univ. (United States)

8987 1 A Off-axis sputter deposition of ZnO films on c-sapphire substrates with buffer layers prepared via nitrogen-mediated crystallization (Invited Paper) [8987-35]

N. Itagaki, Kyushu Univ. (Japan) and Japan Science and Technology Agency (Japan);

K. Matsushima, D. Yamashita, H. Seo, K. Koga, M. Shiratani, Kyushu Univ. (Japan)

8987 1B Role of grain boundaries in ZnO (Invited Paper) [8987-36]

Y. Sato, The Univ. of Tokyo (Japan); Y. Ikuhara, The Univ. of Tokyo (Japan), Japan Fine Ceramics Ctr. (Japan), and Tohoku Univ. (Japan)

8987 ID Electrical and optical properties of ZnO bulk crystals with and without lithium grown by the hydrothermal technique [8987-37]

B. Wang, Wright State Univ. (United States) and Air Force Research Lab. (United States);

B. Claflin, Air Force Research Lab. (United States); M. Callahan, Greentech Solutions, Inc. (United States); Z. -Q. Fang, Wright State Univ. (United States); D. Look, Wright State Univ. (United States), Air Force Research Lab. (United States), and Wyle Labs., Inc. (United States) 
8987 IF ZnO micro/nanocrystals grown by laser assisted flow deposition (Invited Paper) [8987-39] J. Rodrigues, A. J. S. Fernandes, D. Mata, T. Holz, R. G. Carvalho, Univ. de Aveiro (Portugal); R. Fath Allah, T. Ben, D. Gonzalez, Univ. de Cádiz (Spain); R. F. Silva, A. F. da Cunha, M. R. Correia, Univ. de Aveiro (Portugal); L. C. Alves, K. Lorenz, Univ. Técnica de Lisboa (Portugal); A. J. Neves, F. M. Costa, T. Monteiro, Univ. de Aveiro (Portugal)

8987 1G Metal-oxide semiconductor nanostructures for energy and sensing applications (Invited Paper) [8987-40]

J. S. Yu, Y. H. Ko, Kyung Hee Univ. (Korea, Republic of)

$8987 \mathrm{lH} \quad$ Effect of electric field and atmosphere on the processing of nanocrystalline $\mathrm{ZnO}$ (Invited Paper) [8987-41]

B. Dargatz, J. Gonzalez-Julian, O. Guillon, Friedrich-Schiller-Univ. Jena (Germany)

$89871 \mathrm{~J}$ Upconversion properties of $\mathrm{Er}^{3+}$-doped oxyfluoride glass-ceramics containing $\mathrm{SrF}_{2}$ nanocrystals [8987-43]

C. R. Kesavulu, Sri Venkateswara Univ. (India) and Univ. de Sao Paulo (Brazil); K. Kiran Kumar, C. K. Jayasankar, Sri Venkateswara Univ. (India)

8987 IK Flexible binder free functionalized carbon nanotube electrodes for ultracapacitor [8987-89] B. R. Bhat, L. S. Aravinda, K. U. Bhat, National Institute of Technology, Karnataka (India)

\section{SESSION 9 ZNO-BASED TRANSISTORS}

$89871 \mathrm{~L} \quad$ Flexible aluminum-doped zinc-oxide thin-film transistor fabricated on plastic substrates (Invited Paper) [8987-44]

D. Han, Z. Chen, N. Zhao, W. Wang, F. Huang, S. Zhang, X. Zhang, Y. Wang, Peking Univ. (China)

\section{SESSION 10 OXIDE-BASED DETECTORS}

8987 IP High response solar-blind MgZnO photodetectors grown by molecular beam epitaxy (Invited Paper) [8987-54]

W. V. Schoenfeld, M. Wei, R. C. Boutwell, H. Liu, CREOL, The College of Optics and Photonics, Univ. of Central Florida (United States)

$89871 Q \quad$ Contact properties and surface reaction kinetics of single ZnO nanowire devices fabricated by dielectrophoresis (Invited Paper) [8987-55] J. L. Pau, C. García Núñez, A. García Marín, C. Guerrero, P. Rodríguez, Univ. Autónoma de Madrid (Spain); S. Borromeo, Univ. Rey Juan Carlos (Spain); J. Piqueras, Univ. Autónoma de Madrid (Spain) 
8987 IR Controlling the properties of electrodeposited ZnO nanowire arrays for light emitting diode, photodetector and gas sensor applications (Invited Paper) [8987-57]

T. Pauporté, IRCP, CNRS, Ecole Nationale Supérieure de Chimie de Paris (France);

O. Lupan, IRCP, CNRS, Ecole Nationale Supérieure de Chimie de Paris (France) and Technical Univ. of Moldova (Moldova); B. Viana, IRCP, CNRS, Ecole Nationale Supérieure de Chimie de Paris (France); L. Chow, Univ. of Central Florida (United States);

M. Tchernycheva, Institut d' Electronique Fondamentale, CNRS, Univ. Paris-Sud 11 (France)

8987 is Multi-layer insulator for low voltage and breakdown voltage enhancement in electrowetting-on-dielectric [8987-81]

A. Hapsari, Y. H. Won, Korean Advance Institute of Science and Technology (Korea, Republic of)

\section{SESSION 11 OXIDE-BASED LIGHT EMITTERS}

8987 IT Blue/red electroluminescence from hybrid Eu:phosphors/ZnO-nanowires/p-GaN LED (Invited Paper) [8987-48]

B. Viana, T. Pauporte, IRCP, CNRS, Ecole Nationale Supérieure de Chimie de Paris (France): O. Lupan IRCP, CNRS, Ecole Nationale Supérieure de Chimie de Paris (France) and Technical Univ. of Moldova (Moldova); L. Devis, T. Gacoin, Lab. de Physique de la Matière Condensée, CNRS, Ecole Polytechnique (France)

$8987 \mathrm{IU} \quad \beta-\mathrm{Ga}_{2} \mathrm{O}_{3}$ and single-crystal phosphors for high-brightness white LEDs and LDs, and $\beta-\mathrm{Ga}_{2} \mathrm{O}_{3}$ potential for next generation of power devices (Invited Paper) [8987-49]

E. G. Víllora, National Institute for Materials Science (Japan); S. Arjoca, K. Shimamura, National Institute for Materials Science (Japan) and Waseda Univ. (Japan); D. Inomata, K. Aoki, Koha Co., Ltd. (Japan)

8987 IW Investigation of ZnO-based ultraviolet light-emitting diodes (Invited Paper) [8987-51] C.-T. Lee, H.-Y. Chang, National Cheng Kung Univ. (Taiwan)

8987 1X Functional metal oxide nanostructures fabricated by 3D-nanotemplate PLD (Invited Paper) [8987-52]

A. N. Hattori, H. Tanaka, Osaka Univ. (Japan)

8987 IY UV detectors and LEDs in different metal oxide nanostructures (Invited Paper) [8987-53] M. Willander, M. A. Abbasi, K. Khun, M. Hussain, Z. H. Ibupoto, O. Nur, Linköping Univ. (Sweden)

898720 Plasma treatment of $p$-GaN/n-ZnO light-emitting diodes [8987-85]

Y. H. Leung, The Univ. of Hong Kong (Hong Kong, China); A. M. C. Ng, The Univ. of Hong Kong (Hong Kong, China) and South Univ. of Science and Technology of China (China); A. B. Djurišic, W. K. Chan, The Univ. of Hong Kong (Hong Kong, China); P. W. K. Fong,

H. F. Lui, C. C. Surya, The Hong Kong Polytechnic Univ. (Hong Kong, China) 
898722 High-efficiency heterojunction solar cells on crystalline germanium substrates (Invited Paper) [8987-59]

B. Hekmatshoar, D. Shahrjerdi, M. Hopstaken, IBM Thomas J. Watson Research Ctr. (United States)

898723 Material properties of high-mobility TCOs and application to solar cells (Invited Paper) [8987-60]

F. Ruske, S. Schönau, S. Ring, S. Neubert, B. Stannowski, Helmholtz-Zentrum Berlin für Materialien und Energie GmbH (Germany); V. Sittinger, Fraunhofer-Institut für Schicht- und Oberflächentechnik (Germany); S. Götzendörfer, Berliner Glas Surface Technology (Germany); B. Rech, Helmholtz-Zentrum Berlin für Materialien und Energie GmbH (Germany)

898725 Light trapping considerations in self-assembled ZnO nanorod arrays for quantum dot sensitized solar cells (Invited Paper) [8987-62]

C. Y. Luan, K. T. Cheung, Y. Foo, City Univ. of Hong Kong (Hong Kong, China); L. Y. Yu, Q. Shen, The Univ. of Electro-Communications (Japan) and Japan Science and Technology Agency (Japan); J. A. Zapien, City Univ. of Hong Kong (Hong Kong, China)

898726 Oxides for sustainable photovoltaics with earth-abundant materials (Invited Paper) [8987-63]

A. Wagner, M. Stahl, N. Ehrhardt, A. Fahl, J. Ledig, A. Waag, A. Bakin, Technische Univ. Braunschweig (Germany)

898728 Tailor-made $\mathrm{ZnO@SnO}_{2}$ networks for high efficiency photovoltaic devices [8987-82] R. Milan, G. S. Selopal, I. Concina, INO SENSOR Lab., CNR, Univ. degli Studi di Brescia (Italy); M. Epifani, Consiglio Nazionale delle Ricerche (Italy); A. Vomiero, G. Sberveglieri, INO SENSOR Lab., CNR, Univ. degli Studi di Brescia (Italy)

898729 Design and synthesis of new low band gap organic semiconductors for photovoltaic applications [8987-90]

M. G. Murali, Indian Institute of Science (India); U. K. Dalimba, National Institute of Technology, Karnataka (India)

\section{SESSION 13 ENERGY HARVESTING STORAGE: METAL OXIDES AND GRAPHENE}

$89872 \mathrm{C}$ Chemical bonding and stability of multilayer graphene oxide layers (Invited Paper) [8987-67]

C. Gong, The Univ. of Texas at Dallas (United States); S. Kim, S. Zhou, Y. Hu, Georgia Institute of Technology (United States); M. Acik, The Univ. of Texas at Dallas (United States); W. de Heer, C. Berger, A. Bongiorno, E. Riedo, Georgia Institute of Technology (United States); Y. Chabal, The Univ. of Texas at Dallas (United States)

$89872 \mathrm{E} \quad$ Engineering metal oxide structures for efficient photovoltaic devices [8987-70] I. Concina, G. S. Selopal, R. Milan, A. Vomiero, G. Sberveglieri, INO SENSOR Lab., CNR, Univ. degli Studi di Brescia (Italy) 
THIN FILMS AND BULK PROCESSING II

$89872 \mathrm{P}$ Nickel oxide growth on $\mathrm{Si}(111), \mathrm{C}-\mathrm{Al}_{2} \mathrm{O}_{3}$ and FTO/glass by pulsed laser deposition [8987-97]

V. E. Sandana, D. J. Rogers, F. Hosseini Teherani, P. Bove, Nanovation (France);

R. McClintock, M. Razeghi, Northwestern Univ. (United States)

Author Index 


\section{Conference Committee}

Symposium Chairs

David L. Andrews, University of East Anglia Norwich (United Kingdom)

Alexei L. Glebov, OptiGrate Corporation (United States)

Symposium Co-chairs

Jean Emmanuel Broquin, IMEP-LAHC (France)

Shibin Jiang, AdValue Photonics, Inc. (United States)

Program Track Chair

James G. Grote, Air Force Research Laboratory (United States)

Conference Chairs

Ferechteh H. Teherani, Nanovation (France)

David C. Look, Wright State University (United States)

David J. Rogers, Nanovation (France)

Conference Program Committee

Philippe Bove, Nanovation (France)

Ivan Bozovic, Brookhaven National Laboratory (United States)

Won Kook Choi, Korea Institute of Science and Technology

(Korea, Republic of)

Jean-Jacques Delaunay, The University of Tokyo (Japan)

Aleksandra B. Djurišic, The University of Hong Kong (Hong Kong, China)

Michael D. Gerhold, U.S. Army Research Office (United States)

Hanns-Ulrich Habermeier, Max-Planck-Institut für Festkörperforschung (Germany)

Axel Hoffmann, Technische Universität Berlin (Germany)

Masashi Kawasaki, Tohoku University (Japan)

Katharina Lorenz, Instituto Superior Técnico (Portugal)

Andreia Luisa da Rosa, Universität Bremen (Germany)

Tariq Manzur, Naval Undersea Warfare Center (United States)

Tatsuo Okada, Kyushu University (Japan)

Thierry Pauporté, Ecole Nationale Supérieure de Chimie de Paris (France)

Robert Plana, Laboratoiré d'Analyse et d'Architecture des Systèmes

(France) 
Manijeh Razeghi, Northwestern University (United States)

Vinod Eric Sandana, Graphos (France)

Bruno Viana, Ecole Nationale Supérieure de Chimie de Paris (France)

Magnus Willander, Linköping Universitet (Sweden)

Takafumi Yao, Tohoku University (Japan)

Jae Su Yu, Kyung Hee University (Korea, Republic of)

\section{Session Chairs}

1 Transparent Conducting Oxides

Axel Hoffmann, Technische Universität Berlin (Germany)

2 Photon-induced Phenomena

David C. Look, Wright State University (United States)

3 Doping and Band Structure Studies of Oxides

Aleksandra B. Djurišic, The University of Hong Kong (Hong Kong, China)

Guy Garry, Thales Research \& Technology (France)

4 Doping and Band Structure Studies of $\mathrm{ZnO}$

Aleksandra B. Djurišic, The University of Hong Kong (Hong Kong, China)

5 Highly-Correlated Oxides I

Hideki Yamamoto, NTT Basic Research Laboratories (Japan)

Hanns-Ulrich Habermeier, Max-Planck-Institut für Festkörperforschung (Germany)

6 Highly-Correlated Oxides II

Hideki Yamamoto, NTT Basic Research Laboratories (Japan)

Hanns-Ulrich Habermeier, Max-Planck-Institut für Festkörperforschung (Germany)

$7 \quad$ Thin Films and Bulk Processing

David J. Rogers, Nanovation (France)

8 Growth, Properties, and Applications of Nanostructures

Jose Luis Pau Vizcaíno, Universidad Autónoma de Madrid (Spain)

Philippe Bove, Nanovation (France)

9 ZnO-based Transistors

Jose Luis Pau Vizcaíno, Universidad Autónoma de Madrid (Spain) 
10 Oxide-based Detectors

David J. Rogers, Nanovation (France)

Jong-Ho Lee, Korea Institute of Industrial Technology (Korea,

Republic of)

11 Oxide-based Light Emitters

David J. Rogers, Nanovation (France)

Thierry Pauporté, Ecole Nationale Supérieure de Chimie de Paris (France)

12 Energy Harvesting Storage: Materials and Devices

Vinod Eric Sandana, Graphos (France)

Magnus Willander, Linköping Universitet (Sweden)

13 Energy Harvesting Storage: Metal Oxides and Graphene

Bruno Viana, Ecole Nationale Supérieure de Chimie de Paris (France) 


\title{
Introduction
}

This volume contains the proceedings of the fifth annual "Oxide Based Materials and Devices" conference which was held at SPIE Photonics West in San Francisco. The conference had its most successful year to date in 2014 , with 75 oral and 20 poster presentations of excellent quality from groups in 23 countries covering an ever-widening range of both materials and applications. The conference also attracted a growing industrial interest, with presentations from 20 companies ranging in size from start-ups to multinationals.

The chairs wish to thank the SPIE team for their exemplary organization plus all those who contributed and made this a very lively and stimulating conference. We would also especially like to recognize the efforts of those who took the time to contribute a paper and create this valuable and searchable record of the meeting.

We are looking forward to seeing you in San Francisco next February for "Oxide Based Materials and Devices VI"!

\author{
Ferechteh H. Teherani \\ David C. Look \\ David J. Rogers
}

